\title{
Analysis Factors Affecting Students' Satisfaction with Academic Services Based on Servqual
}

\author{
Girang Razati, Sumiyati, Masharyono \\ Universitas Pendidikan Indonesia \\ Bandung, Indonesia \\ girangrazati@upi.edu
}

\begin{abstract}
Colleges are required to continue to improve in the satisfaction of students in the service provided. The purpose of this research to understand factors that which influences student satisfaction seen from servqual. Methods used explanatory survey. The subject in this study was 201 students. Data analysis using analysis factor with the help SPSS. The result showed that the factors that affect customer satisfaction that is tangible, empathy, assurance, responiveness and realiability. College in improving student satisfaction must consider factors tangible, empathy, assurance, and realiability responiveness
\end{abstract} student

Keywords-Customer Satisfaction, Servqual, Collage, and

\section{INTRODUCTION}

Today a nonprofit organization and profit are required to prepare to be organization ready to compete with other organizations [1]. One nonprofit organization that is institutions a college education. Educational institutions this is an organization that produces education services purchased by consumers.

Education is an important need to prepare a better future. The changes in the education system, raises new educational institutions, especially private school. Almost of them were competing with each others to improving their quality service in order to complied customer's (students) satisfactions. The rate of student's satisfaction regarding its service can be measured by comparing between student's expectations of quality service against the fact that they received [2]

The success of the college is very much determined by the success of the faculty as work units in in providing high quality services to customers in this student. To achieve satisfaction high, there needs to be an understanding of what is wanted by consumers, by developing commitment everyone who is in institutions to meet the needs of consumers [3]. An aspect comprehensive in service system is identify to measurement services. The benefit of the measurement of service, the quality of must be viewed from five perspective the content, refugees, structure, outcome, and impact [4].

Customer satisfaction which is a the state of fulfill desire, hope, and the need for customers. Customer satisfaction with a company's products or services is often seen as the key to a company's success and long-term competitiveness [5]. Relationship marketing was found to represent an effective weapon for improving both relationship quality and beneficiaries' satisfaction with service provision. Charities that "listened" to their beneficiary clients (e.g. by encouraging feedback) and which interacted with them on a regular basis were regarded as being exceptionally good at relationship marketing. Relationship quality as well as actual service quality induced beneficiaries to want to recommend a charity to other people and to engage in positive word-of-mout [6]

Based on information can be seen factors affecting student's satisfaction to academic services based on servqual.

\section{LITERATURE STUDY}

\section{A. Education services}

Education conscious and deliberate effort to create an atmosphere of learning and the learning process so that learners are actively developing the potential for him to have the spiritual power of religion, self-control, personality, intelligence, character, and skills needed him, society, nation and state [7].

A process by which cultivate ability attitudes and other shafes behavior in the communities of which he lives, the social process whereby the faced with environmental influences chosen and controlled (especially come from school), so that he can obtain or undergo development social skills and ability individuals steady [8]

\section{B. Customer Satisfaction}

Customer satisfaction is post purchase evaluation where alternative selected at least results from (outcame) equal or beyond hope customers [9]. A theory that explains how satisfaction or unsatisfaction consumers formed is on expectancy disconfirmation model, who dressing that pleasure and discontent consumers is the impact of comparison between hope consumers before a purchase with it obtained consumers from the produce purchased.

Dissatisfaction because the cause of as: not as expected by the fact, services during the process enjoy services unsatisfactory, behavior personnel unsatisfactory, the atmosphere and the physical condition of environmental support, the cost of too high, because the too far, a lot of time wasted with the price is not in accordance, promotion /advertising sententious, not in accordance with the fact [10] 


\section{SERVQUAL}

Service Quality as the delivery of excellent or superior service relative to custumer expectations [11]

There are two the main factors that affects the quality of services: expected service and perceived service. When services received or perceived as expected, so the quality of services in good perceptions and satisfying. If services they received is more lower than expected, so the quality of services in not good perceptions. If the services received lower than expected, then the perception of service quality poor. Thus good where abouts of the quality of services depending on the ability of service providers in meet the expectations of consumers consistently.

Educational institutions offers a lot of quality service not just education alone but also other, for example boarding, food, counseling, planning career, guidance, library, computer, and others [12]. Large width of poor quality of is consumers. Their judgments of quality is generally divided into four view, namely:
1) Corformance to standards or specifications
2) Process quality
3) Outcome quality
4) Consistency

\section{Dimensions of Quality Servce}

Quality of services includes some dimensions, the performance, reability, conformance, durability, serviceability, aesthetics, and perceived quality. Quality dimensions on service industry namely [13]:

1) Communication, the communication or relations between the jsa with providers.

2) Credibilitty, the trust the recipients of service providers.

3) Security, namely security at services offered.

4) Knowing the customer, namely understanding of the service providers with the recipient services or understanding providers against a need and hope the customer service.

5) Tangibles, namely that in providing services to customers must be measured or made its standard.

6) Reliabilitty, namely providers consistency work and the ability to services covenant the recipients of service.

7) Competence, the ability or providers skills needed everyone in company to provide services to recipients services.

8) Access, namely ease providers to contact by the customer service or receiver.

9) Coustery, namely modesty, respect, attention, and equality in relation to personnel

\section{E. Measurement The Quality Of Service}

Measuring the quality of ministry or service means evaluate or compare the performance of a service at a set of the standard established first. Instrument is aimed at knowing hope consumers and evaluate various services offered by the services. Besides measuring hope and perception customers, instrument it was one can measure the gap that is in model the quality of services.

\section{RESEARCH METHODOLOGY}

Methods in this research is explanatory survey. The subject in this study was 241 students at Universitas Pendidikan Indonesia. Data collection with questionnaire. Data Analysis techniques used use factors analysis with help SPSS.

\section{RESULTS AN D DISCUSSION}

Variable tangible in value respondents of $73.6 \%$ and included in a category good. This needs to be improved again by Universitas Pendidikan Indonesia in order to increase satisfaction students especially in matters completeness the waiting room so the university students not get bored when waiting for. Variable empathy in value respondents of 75, $5 \%$ and included in a category good. Are still needs to be improved again by Universitas Pendidikan Indonesia in order to increase satisfaction students especially in matters responding to a complaint and recommendations. Variable assuarnce in value respondents of 75,5\% and included in a category good. Are still needs to be improved again by Universitas Pendidikan Indonesia in order to increase satisfaction students especially in matters of informing and guidance must be clear.

Variable responsiveness in value respondents of $76.3 \%$ and included in a category good. Are still needs to be improved again by Universitas Pendidikan Indonesia in order to increase satisfaction students especially in matters of promptness officers in serving customer (students). Variable reliability in the value of $76,9 \%$ respondents and included in category either. But still need to be increased again Universitas Pendidikan Indonesia by parties in an effort to increase student satisfaction especially in terms of thoroughness in working on its duties and exactness in open office hours.

As a whole variables get assessment the greatest namely reliability as much as 76,9\% and the lowest respondents assess variable tangible as much as $73.6 \%$. It was because Universitas Pendidikan Indonesia has not been have facilities and infrastructure good and one of his campaign namely by construction of buildings lecture new to accommodate the room and the creation of teaching and learning activities conducive.

Overall variables get assessment the greatest namely reliability as much as 76,9\% and the lowest respondents assess variable tangible as much as $73.6 \%$. It was because Universitas Pendidikan Indonesia has not been have facilities and infrastructure good and one of his campaign namely by construction of buildings lecture new to accommodate the room and the creation of teaching and learning activities conducive.

\section{Factors that affects customer satisfaction}

Table I about KMO and Barlett's test it can be seen that value KMO measure of sampling adecuancy of 0,846 with the significance in 0,000. This shows that the total amount KMO 
greater than 0.5 and significance in smaller than 0,005 , so that data on top can continue to analyzed further.

\section{TABLE I. KMO AND BARLETT'S TEST}

\begin{tabular}{lll}
\hline Kaiser-Meyer-Olkin Measure of Sampling Adequacy. & 0.845 \\
Bartlett's Test of Sphericity & Approx. Chi-Square & 721.363 \\
& df & 10 \\
& Sig. & 0.000 \\
\hline \multicolumn{2}{r}{${ }^{\text {a. }}$ Source: the results of data processing, 2015 }
\end{tabular}

Table II about Anti Image Matrices, based on table anti image matrices it can be seen that point for each variables to be researched have a value of MSA above 0.5 as: Tangible: 0,850; Empathy: 0,810; Assurance: 0,901; Responsiveness: 0,815; and Reliability: 0,864. In connection with the MSA on 0,5 so it can be concluded that variables as tangible, empathy, assurance, responsiveness, and realibility influences customer satisfaction.

The link between service quality and customer satisfaction has been investigated [14]. Coupled with the weight of the evidence in the emerging services literature, suggest that consumer satisfaction is best described as moderating the service quality/purchase intention relationship [15]. Service quality, perceived value and customer satisfaction are variables of high interest to marketers. These variables have been suggested to have an influence on customers' postpurchase behavior [16].

Service quality positively influences both perceived value and customer satisfaction; perceived value positively influences on both customer satisfaction and post-purchase intention; customer satisfaction positively influences postpurchase intention; (service quality has an indirect positive influence on post-purchase intention through customer satisfaction or perceived value; among the dimensions of service quality, "customer service and system reliability" is most influential on perceived value and customer satisfaction, and the influence of "content quality" ranks second; the proposed model is proven with the effectiveness in explaining the relationships among service quality, perceived value, customer satisfaction, and post-purchase intention in mobile added-value services [17]

TABLE II. ANTI IMAGE MATRICES

\begin{tabular}{|c|c|c|c|c|c|c|}
\hline & & Tangible & Empathy & Assurance & Responsiveness & Realibility \\
\hline Anti-image & Tangible & 446 & -.181 & -.074 & .004 & -.082 \\
\hline \multirow[t]{4}{*}{ Covariance } & Empathy & -.181 & .356 & -.019 & -.145 & .005 \\
\hline & Assurance & -.074 & -.019 & .475 & -.107 & -.111 \\
\hline & $\begin{array}{l}\text { Responsiven } \\
\text { ess }\end{array}$ & .004 & -.145 & -.107 & .310 & -.143 \\
\hline & Realibility & -.082 & .005 & -.111 & -.143 & .420 \\
\hline Anti-image & Tangible & $.850^{\mathrm{a}}$ & -.455 & -.161 & .011 & -.190 \\
\hline \multirow[t]{4}{*}{ Correlation } & Empathy & -.455 & $.810^{\mathrm{a}}$ & -.045 & -.437 & .013 \\
\hline & Assurance & -.161 & -.045 & $.901^{\mathrm{a}}$ & -.278 & -.249 \\
\hline & $\begin{array}{l}\text { Responsiven } \\
\text { ess }\end{array}$ & .011 & -.437 & -.278 & $.815^{\mathrm{a}}$ & -.396 \\
\hline & Realibility & -.190 & .013 & -.249 & -.396 & $.864^{a}$ \\
\hline
\end{tabular}

\section{CONCLUSIONS AND SUGGESTIONS}

\section{A. Conclusions}

Based on the research done described above can be concluded that factors affecting customer satisfaction that is tangible, empathy, assurance, responiveness and realiability.

\section{B. Suggestions}

Based on the results of respondent's response that needs to be improved by Universitas Pendidikan Indonesia in the service of academic which are in it tangible especially in matters completeness facilities the waiting room. Variable empathy in terms of complaints and suggestions met with good. While for variables assurance that needs to be improved especially in matters information and guidance given clearly. For variables responsiveness that needs to be improved in especially in terms of officers sprightly and ready in serving .And for variables reliability especially in matters opening hours in accordance with their needs students and officers minutely in do their tasks

\section{REFERENCES}

[1] Indrajit RE, Djokopranoto R. Manajemen perguruan tinggi modern. Andi; 2006.

[2] RIANTO IV. Analisis Kualitas Layanan Jasa Pendidikan Sma Krista Mitra Semarang . Universitas Diponegoro.2011.

[3] Handayani, R, Termias T. K., dan Ratminto. Analysis Satisfaction Users To Services National Library Provincial Special Region Of Yogyakarta. Sosiosains, Volume 17 Nomor 2, April 2003. Post Graduated Fisipol UGM. Yogyakarta.2003.

[4] Ayu Made, I Gusti dan Desak Putu Eka Nilakusumawati. (2008). FaktorFaktor Penentu Kepuasan Mahasiswa terhadap Pelayanan Fakultas sebagai Lembaga Pendidikan (Studi Kasus di MFMIPA Universitas Udayana). Cakrawala. November 2008. Th XXVI. No.3.

[5] Hennig-Thurau T, Klee A. The impact of customer satisfaction and relationship quality on customer retention: A critical reassessment and model development. Psychology \& marketing. 1997 Dec 1;14(8):73764.

[6] Bennett R, Barkensjo A. Relationship quality, relationship marketing, and client perceptions of the levels of service quality of charitable organisations. International journal of service industry management. 2005 Feb 1;16(1):81-106.

[7] Law No.20 year 2003 on the national education system

[8] Ihsan, Fuad, Basic Education, Rineka Cipta, Jakarta. 2003

[9] Fandy Tjiptono. Marketing Strategic, Yogyakarta: Penerbit Andi. 2004

[10] Buchari Alma, Marketing Management and Service Marketing, CV Alfabeta, Bandung. 2004.

[11] Zeithaml, Valarie A. And Mary Jo Bitner, (2001), Service Marketing, Mc Graw Hill Companies For Manufactures and Export, Boston. Quality Assessment", Marketing Reseach a Magazine of Management \& Applications, Spring, p.6.2001

[12] Kotler, Philip, Marketing Management, Prentice Hall International.2005

[13] Ariani, Wahyu. Service Operations Management. Yogyakarta: Graha Ilmu.2009

[14] Sureshchandar GS, Rajendran C, Anantharaman RN. The relationship between service quality and customer satisfaction-a factor specific approach. Journal of services marketing. 2002 Jul 1;16(4):363-79.

[15] Tarn JL. The effects of service quality, perceived value and customer satisfaction on behavioral intentions. Journal of Hospitality \& Leisure Marketing. 1999 Dec 1;6(4):31-43.

[16] Caruana A. Service loyalty: The effects of service quality and the mediating role of customer satisfaction. European journal of marketing. 2002 Aug 1;36(7/8):811-28. 
[17] Kuo YF, Wu CM, Deng WJ. The relationships among service quality, perceived value, customer satisfaction, and post-purchase intention in mobile value-added services. Computers in human behavior. $2009 \mathrm{Jul}$ 31;25(4):887-96. 